\title{
Community Analysis of Soil Acarina in a Natural Forest and Jhum Land Ecosystem of Mokokchung, Nagaland.
}

\author{
${ }^{1}$ Kruolalie Tsurho, ${ }^{2}$ Bendang Ao \\ ${ }^{1}$ Assistant Professor, Department of Zoology, Fazl Ali College, Mokokchung, Nagaland.India, \\ ${ }^{2}$ Assistant Professor, Department of Zoology, Nagaland University, Lumami, Zunheboto, Nagaland, India,
}

\begin{abstract}
The present study was carried out in two adjacent areas of a natural forest and jhumland ecosystem in Mopungchuket village and Chuchuyimpang village respectively, under Mokokchung district, Nagaland, which lies at $26^{\circ} 11^{\prime} 36^{\prime \prime}$ North latitude and in between $94^{\circ} 17^{\prime} 44^{\prime \prime}$ to $94^{\circ} 45^{\prime} 42^{\prime \prime}$ (E) longitude. The study was conducted during January 2009 to December 2011. The vertical distribution and abundance of total soil Acarina were found to be more in the natural forest ecosystem $\left(424.82 \times 10^{2} \mathrm{~m}^{-2}\right)$ than jhum land ecosystem $\left(264.70 \times 10^{2} \mathrm{~m}^{-2}\right)$ and showed a significant decrease from upper layer to deeper layers i.e., from $0 \mathrm{~cm}$ to $30 \mathrm{~cm}$ depth. The soil Acarina showed a higher population in the natural forest, with the different values during the different seasons being $231.37 \times 10^{2} \mathrm{~m}^{-2}$ (rainy season), $116.20 \times 10^{2} \mathrm{~m}^{-2}$ (summer) and $77.25 \times 10^{2} \mathrm{~m}^{-2}$ (winter season) respectively. The physico-chemical factors exhibited significant correlation with soil Acarina except soil potassium. The community analysis was carried out for soil Acarina because they are one of the major groups of soil microarthropods and their contributions are maximum in term of species, abundance and distribution.
\end{abstract}

Key words: Community analysis, Acarina, microarthropods, natural forest and jhum land.

\section{Introduction}

Acarina are minute, free-living soil and litter microarthropods found abundantly and are a dominant group in the soil-litter sub-system. These microarthropods play an important role in nurturing or maintaining the sustainability of an ecosystem through decomposition and mineralization of leaf litter. They enrich the soil fertility via decomposition of organic matter, soil mineralization, maintenance of soil physical structure, nutrient cycling, energy flow and enhancing primary productivity (Badejo and Staalen, 1993; Hofer et al., 2001; Yang and Chen, 2009). In a natural forest ecosystem, the concentration of soil Acarina is higher which is due to canopy with vegetation cover, accumulation of litter and optimum physico-chemical factors favouring these microarthropods, but jhum land ecosystems show negative impact due to disturbance in the type of vegetative cover, lack of canopy, physico-chemical properties of soil and depth of litter etc. (Price, 1973; Seastedt, 1984; Badejo and Staalen, 1993; Wardle and Giller, 1996). Acarina are divided into four sub orders viz (i) Cryptostigmata (oribatid), (ii) Mesostigmata (Gamasida), (iii) Prostigmata (Actinediad), and (iv) Astigmata. The Cryptostigmata are also called beetle mites for resembling small beetles, and are found in leaf litter, under bark and stones. The Mesostigmata are generally flatened, tick-like mites, and are found as predaceous, scavengers or in parasitic form on leaf litter, humus and soil. Prostigmata are delicate, white to colourless and subject to desiccation, some are free living - occurring in litter, moss or water and vary in food habits. Astigmata are free living and are commonly called cheese mites having no stigma or trachea. They are seen associated with highly organic, decomposing material such as manure. Appreciable work on their classification has been done by Bhandari \& Somani (1994).

\section{$2.1 \quad$ Study Sites}

\section{Materials And Methods}

The present study was carried out in two adjacent areas of natural forest and jhum land ecosystems in Mopongchuket village and Chuchuyimpang village under Mokokchung district, Nagaland which lies at $26^{\circ} 11^{\prime} 36^{\prime \prime}$ "North latitude and in between $94^{\circ} 17^{\prime} 44^{\prime \prime}$ to $94^{\circ} 45^{\prime} 42^{\prime \prime}$ (E) longitude. The forest site comprised of rich vegetation which had not been disturbed for more than twenty years while the jhum land had almost no vegetation due to frequent human activities and interference.

The natural forest comprised of rich vegetation with a distinct vertical stratification. The canopy layer had an average height of 20 metres or more, comprising of different tree species like Albizia procera, Schima wallichii, Alnus nepalensis, Castinopsis indica, Lithocarpus elegans, Michellia champaca and Persia villosa. Emergent trees that overshoot the canopy layers were not present. The smaller trees mostly belong to the families of Lauraceae, Euphobiaceae, Araliaceae, Ficaseae and Rubiaceae. The average height of these members is 5 to $15 \mathrm{mts}$. The ground flora is rich and epiphytes, climbers and lianas were also found to be growing abundantly. The jhum land, on the other hand was not as well stratified as the natural forest. The tree species present are the species that were left uncut while clearing the forest and the stumps that survived the jhum 
cultivation. Quercus serrata, Erythrina striata, Albizia procera, Schima walichii were the dominant species present in the jhum areas.

\subsection{Climate}

The climate of the area is monsoonal, with warm moist summers and cool dry winters. The meteorological data based on three years (2009-2011) as shown in tabular as well as graphical forms (tables 1-3 and figures 1-3) reveals that June to October constitutes wet months and November to May the dry months. The dry period can be further divided into summer (March to May) and cool dry season (November to February). Thus there is distinct summer (March to May), rainy (June to October) and winter (November to February) seasons. March constitutes the transitional month between winter and summer whereas October is the transitional month between rainy and winter season.

The maximum and minimum air temperature was $21.4^{\circ} \mathrm{C}$ (August) and $6.3^{\circ} \mathrm{C}$ (January) respectively in 2010 (Average: $\operatorname{Max}=21.4^{\circ} \mathrm{C} \quad \operatorname{Min}=8.1{ }^{\circ} \mathrm{C}$ ). The maximum and minimum relative humidity was $85 \%$ (August) in 2009 and 35.55 (December) in 2011 respectively (Average: Max $=83.3 \% \quad$ Min $=54.5 \%$ ). The maximum and minimum total rainfall was $972.5 \mathrm{cms}$ (July) in 2011 and the minimum was $3.7 \mathrm{cms}$ (March) in 2009 (Average: $\operatorname{Max}=572.5 \mathrm{~cm} \quad$ Min $=11.3 \mathrm{~cm}$, total average rainfall $=1859.93 \mathrm{cms}$ ).

\subsection{Sampling and Extraction}

In both the forest and jhum land ecosystems, the sampling collection sites were divided according to the elevation because of the terrain viz. upper elevation site, middle elevation site and lower elevation site. In each elevation site, three different plots having a size of $10 \mathrm{~m} \times 10 \mathrm{~m}$, each at 25-30 m apart were selected from where soil samples were taken randomly. Soil samples were taken at one month intervals in the middle week of each month during the study period. All the collections were made in the mornings between 10:00 and 11:00 AM. The soil samples were collected with the help of iron cylindrical core with sampler size of $3.925 \mathrm{~cm}$, which are $10 \mathrm{~cm}$ in depth and $5 \mathrm{~cm}$ in diameter. Three replicates were collected from each area or collection site. The samples were immediately bound in polytene bags, labelled and brought to the laboratory for analysis. In each study site a total of 1944 soil samples were collected during the whole study period. The soil samples were than packed and brought to the laboratory within an average of one hour after the field collection. The samples were then divided into sections and placed in a Tullgren funnel as described by Crossley and Blair (1991). The soil microarthropods were extracted into collecting vials containing 70\% alcohol. After the extraction, the vials and the contents were transferred into a petridish and vials were washed several times with $70 \%$ alcohol. The extracted soil microarthropods were preserved in $70 \%$ alcohol to which few drops of glycerine were added to prevent desiccation. Identification and counting was done under a binocular microscope, and density calculated.

\subsection{Soil Analysis}

Physico-chemical factors of the soil like temperature, moisture, $\mathrm{pH}$, organic carbon, total nitrogen, available phosphorus, and potassium were analyzed during each sampling period in order to study the impact of these factors in the population changes of soil microarthropods. The methodologies utilized for each are as follows: Soil temperature (soil thermometer), Soil moisture content (gravimetric method according to Misra, 1968 and Wilde et al., 1985), Soil pH (portable glass electrode pH meter (according to Jackson, 1958), Soil organic carbon (oxidation calorimetric method i.e., modified Walkey and Black method according to Anderson and Ingram, 1993), Soil total nitrogen (acid digestion Kjeldahl procedures according to Anderson and Ingram, 1993), Phosphorus (ammonium molybdate stannous chloride method according to Sparling et al., 1985), Potassium (flame photometer according to Steward, 1971).

\subsection{Community Analysis}

In community analysis, species diversity and community similarity were analyzed for Acarina using the following formulae:

(i) Species diversity (number of species) or species richness was calculated after Margalef (1968).

$\mathrm{Da}=(\mathrm{S}-1) / \log \mathrm{N}$

Where,

$$
\begin{aligned}
\mathrm{Da} & =\text { Margalefs Index } \\
\mathrm{S} & =\text { No. of species } \\
\mathrm{N} & =\text { Total no. of individuals. }
\end{aligned}
$$

(ii) Measure of species diversity based on information theory or related to the concept of uncertainty was calculated after Shannon and Wiener (1949),

where, 


$$
\mathbf{H}^{\prime}=-\sum_{\mathbf{i}=\mathbf{1}} \mathbf{P i} \log \mathbf{p i}
$$

$\mathrm{H}^{\prime}=$ Measure of Shannon - Wiener Diversity

$\mathrm{S}=$ Total no. of species in a sample

$\mathrm{Pi}=$ Proportion of the total number of individuals occurring in species $\mathrm{i}$.

(iii) The maximum possible diversity of $\mathrm{H}^{\prime}$ or $\mathrm{H}$ max' was calculated using the following formula:

$$
\mathrm{H} \max { }^{\prime}=\log _{2} \mathrm{~S}
$$

Where, $\mathrm{S}=$ Number of species or category

\section{Result And Discussion}

Community analysis of Acarina populations in both the forest and jhumland ecosystems showed maximum abundance, and species diversity in rainy season and slowly decreased in summer and winter seasons. Seasonal differences in the abundance of soil arthropods have been demonstrated by various workers (Salt, 1952; Davis, 1963; Block, 1966; Nijima, 1971; Usher, 1975). These workers reported that microarthropods undergo enormous fluctuations in numbers, these being susceptible to small changes or factors that influence population size. Wallwork (1970), Fujikawa (1970) and Anderson (1988) suggests that the temporal pattern has been related to transition from one season to another which is mostly due to shift in soil moisture and temperature.

The Data analysis of Acarina (Table no. 1 \& 2) using Margalefs index (Da) and Shannon-Wiener diversity index $\left(\mathrm{H}^{\prime}\right)$ show more diversity in forest than in the jhum land ecosystem. In forest ecosystem, maximum value of diversity $\left(\mathrm{Da}=5.882, \mathrm{H}^{\prime}=3.682\right)$ was shown during summer and rainy season and minimum during winter season, while in jhumland ecosystem, maximum value of diversity $\left(\mathrm{Da}=4.771, \mathrm{H}^{\prime}=\right.$ 3.332) were recorded in rainy and summer season respectively. Hmax' of Acarina (Table no. $1 \& 2$ ) was found to be higher in forest ecosystem as compared with jhumland ecosystem. In forest ecosystem, Hmax' value was highest in summer season (4.164) and lowest in winter seasons (2.113) respectively. While in jhumland ecosystem, Hmax' value was highest in rainy season (3.110) and lowest in winter (2.003) respectively. The higher diversity indices in both the study sites have been recorded higher during summer and rainy season in all the soil layer i.e., at $0-10 \mathrm{~cm}, 10-20 \mathrm{~cm}$ and $20-30 \mathrm{~cm}$, while lower diversity indices have been recorded in all the soil layers, in both the study sites.

A total of fifteen (15) soil Acarina species were identified from the two study sites i.e. forest and jhum land ecosystems (Table no. $3 \& 4$ ). The result from the two study site showed variation in its community structure. Overall the number of individuals, species and the value of diversity were found to be higher and more consistent in the forest ecosystem than that in the jhumland ecosystem. It was also seen that some of the species of soil Acarina that were found in a natural forest ecosystem were totally absent in jhumland which brings about a decrease or disappearance of the least abundant species, while the most abundant species persist (Gurrea et al., 2000).

Table 1: Species diversity of the total identified Acarina in different seasons at different soil

\begin{tabular}{|c|c|c|c|c|c|}
\hline \multirow[t]{2}{*}{ Area } & \multirow[t]{2}{*}{ Soil layers } & \multirow[t]{2}{*}{ Season } & \multicolumn{3}{|c|}{ Data analysis } \\
\hline & & & Margalef's Index (Da) & Diversity(H') & Hmax' \\
\hline \multirow{9}{*}{$\begin{array}{l}\text { Forest } \\
\text { ecosystem }\end{array}$} & $0-10 \mathrm{~cm}$ & Summer & 5.668 & 3.315 & 3.445 \\
\hline & $0-10 \mathrm{~cm}$ & Rainy & 4.965 & 3.682 & 3.228 \\
\hline & $0-10 \mathrm{~cm}$ & Winter & 5.354 & 3.772 & 3.635 \\
\hline & $10-20 \mathrm{~cm}$ & Summer & 5.882 & 2.195 & 2.541 \\
\hline & $10-20 \mathrm{~cm}$ & Rainy & 5.231 & 2.953 & 2.407 \\
\hline & $10-20 \mathrm{~cm}$ & Winter & 5.325 & 3.121 & 2.113 \\
\hline & $20-30 \mathrm{~cm}$ & Summer & 5.342 & 3.325 & 4.164 \\
\hline & $20-30 \mathrm{~cm}$ & Rainy & 5.335 & 3.651 & 4.091 \\
\hline & $20-30 \mathrm{~cm}$ & Winter & 4.617 & 3.215 & 3.951 \\
\hline
\end{tabular}
depth in forest ecosystem. 
Table 2 : Species diversity of the total identified Acarina in different seasons at different soil depth in jhumland ecosysystem.

\begin{tabular}{|c|c|c|c|c|c|}
\hline \multirow[t]{2}{*}{ Area } & \multirow[t]{2}{*}{ Soil layers } & \multirow[t]{2}{*}{ Season } & \multicolumn{3}{|c|}{ Data analysis } \\
\hline & & & Margalef's Index (Da) & Diversity(H') & Hmax $^{\prime}$ \\
\hline \multirow{9}{*}{$\begin{array}{l}\text { Jhum land } \\
\text { ecosystem }\end{array}$} & $0-10 \mathrm{~cm}$ & Summer & 3.343 & 2.011 & 2.428 \\
\hline & $0-10 \mathrm{~cm}$ & Rainy & 4.128 & 2.528 & 2.171 \\
\hline & $0-10 \mathrm{~cm}$ & Winter & 3.665 & 2.658 & 2.223 \\
\hline & $10-20 \mathrm{~cm}$ & Summer & 3.559 & 3.332 & 2.331 \\
\hline & $10-20 \mathrm{~cm}$ & Rainy & 4.771 & 3.143 & 3.110 \\
\hline & $10-20 \mathrm{~cm}$ & Winter & 3.325 & 3.000 & 2.003 \\
\hline & $20-30 \mathrm{~cm}$ & Summer & 4.356 & 2.447 & 2.285 \\
\hline & $20-30 \mathrm{~cm}$ & Rainy & 3.371 & 2.613 & 2.311 \\
\hline & $20-30 \mathrm{~cm}$ & Winter & 3.551 & 2.530 & 2.513 \\
\hline
\end{tabular}

Table 3 : Distribution of Acarina species in different seasons of forest ecosystem

\begin{tabular}{|c|c|c|c|c|}
\hline SI.No & Species & Summer & Rainy season & Winter \\
\hline 1 & Allosuctobelba sp & +++ & +++ & +++ \\
\hline 2 & Bdella longicornis & +++ & - & - \\
\hline 3 & Cosmozercon sp & - & - & ++ \\
\hline 4 & $\begin{array}{l}\text { Dendrohermannia } \\
\text { monstrouse }\end{array}$ & - & ++ & ++ \\
\hline 5 & Gamasellus sp & ++ & ++ & +++ \\
\hline 6 & Hermannia sp & ++ & ++ & - \\
\hline 7 & Haplozetes sp & +++ & ++ & +++ \\
\hline 8 & Limnozetes palinerae & ++ & +++ & - \\
\hline 9 & Nothrus palustrus & ++ & +++ & + \\
\hline 10 & Ololaelaps sp & ++ & ++ & - \\
\hline 11 & Oribotritia sp & +++ & +++ & ++ \\
\hline 12 & Pergalumna sp & ++ & ++++ & - \\
\hline 13 & Robustocheles sp & ++ & +++ & +++ \\
\hline 14 & Tectocepheus sp & ++ & - & - \\
\hline 15 & Uropoda cassidea & - & ++ & ++ \\
\hline
\end{tabular}

Table 4 : Distribution of Acarina species in different seasons of jhumland ecosystem.

\begin{tabular}{|c|c|c|c|c|}
\hline Sl.No & Species & Summer & Rainy season & Winter \\
\hline 1 & Allosuctobelba sp. & +++ & +++ & ++ \\
\hline 2 & Bdella longicornis & +++ & +++ & ++ \\
\hline 3 & Dinychus sp. & - & ++ & +++ \\
\hline 4 & Hermannia sp. & +++ & ++ & - \\
\hline 5 & Haplozetes sp. & +++ & +++ & +++ \\
\hline 6 & Limnozetes palinerae & ++ & +++ & - \\
\hline 7 & Ololaelaps sp & ++ & +++ & ++ \\
\hline 8 & Oribotritia sp & - & ++++ & - \\
\hline 9 & Pergalumna sp & ++ & ++ & - \\
\hline 10 & Robustocheles sp & - & + & ++ \\
\hline 11 & Tectocepheus sp & ++ & ++ & +++ \\
\hline 12 & Cosmozercon sp & ++ & +++ & - \\
\hline 13 & Gamasellus sp & +++ & +++ & ++ \\
\hline 14 & Pergalwnna sp. & ++ & +++ & +++ \\
\hline 15 & Poecilochirus & ++ & +++ & - \\
\hline
\end{tabular}

$\begin{array}{llll}+++ & = & \text { High } \\ ++ & = & \text { Moderate } \\ + & = & \text { Low } \\ - & = & \text { Absent }\end{array}$

\section{References}

[1]. Anderson, J.M., 1988. Spatiotemporal effects of invertebrates on soil processes. Biol. Fertil. Soils. 6, $216-227$.

[2]. Anderson, J. H. and Ingram, J. S. (1993). Tropical soil biology and fertility. A handbook of method. UK. C.A.B. Int.

[3]. Badejo, M. A. and Van Straalen, N. M. (1993). Seasonal abundance of Springtails in two contrasting Environments. Biotropica. 25: 222-228.

[4]. Bhandari, S. C. and Somani, L. L. (1994). In "Ecology and Biology of soil organisms", Agrotech publishing Academy, Udaipur.

[5]. Block, W. C. (1966). Seasonal fluctuations and distribution of mite populations in moorland soil with a note on biomass. J. Anim. Ecol. 35: 487-503.

[6]. Crossley, D. A., Blair, J. M. (1991). A high-efficiency, low-technology Tullgren-type extractor for soil microarthropods. Agric. Ecosyst. Environ. 34, 187-192.

[7]. Davis, B. N. K. (1963). A study of microarthropod communities in mineral soils near Corby Northants. J. Animal Ecol. 32: 49-71. 
[8]. Fujikawa, T. (1970). Distribution of soil animals in three forests of Northern Hokkaido I I Horizontal and vertical distribution of Oribatid mites (Acarina: Cryptostigmata). App. Ent. Zool. 5(40): 208-212.

[9]. Gurrea, P., Ferrin, J. M.,Martin, J., Perez, F., Ruiz, M. and Simon, J. C. (2000). Loss of biodiversity due to reforestation in central Spain (Lepidoptera Papilionoidea; Coleoptera Curculionidae; Collembola). Belgian Journal of Entomology. 2: 149-170.

[10]. Hofer H, Hanagarth W, Garcia M, Martius C, Franklin, Rombke J and Beck L (2001). Structure and function of soil fauna communities in Amazonian anthropogenic and natural ecosystems. European journal of soil Biology 37. $229-235$.

[11]. Jackson, M. L. (1958). Soil chemical analysis. Prentice Hall Inc, New Jersey, USA.

[12]. Margalef, R. (1968). Perspectives in ecological theory. University of Chicago Press, Chicago.

[13]. Misra, R. (1968). Ecology work book. Oxford and IBH Pub. Co. Calcutta, India.

[14]. Nijima, K. (1971). Seasonal changes in Collembolan population in a warm temperate forest of Japan. Pedobiologia. $11: 11$-26.

[15]. Price, D. W. (1973). Abundance and vertical distribution of microarthropods in the surface layers of a California pine forest soil. Hilgardia. 42: 121-174.

[16]. Seastedt, T. R. (1984). The role of microarthropods in decomposition and mineralization processes. Ann. Rev. Entom. 29: $25-46$.

[17]. Shannon, C. E. and Wiener, W. (1949). The mathematical theory of communication. Urbana III; Univ. Illionis Press. pp. 117.

[18]. Sorensen, T. (1948). A method of establishing group of equal amplitude in plant sociology based on the similarity of species content and its application to analysis of the vegetation Danish commons. Biol. Skr. 5: 1-34.

[19]. Sparling, G. P. and Shale, K. N. (1985). Quantifying the contribution from the soil microbial biomass to the extractable levels of fresh and air dried soils. Aust. J. of soil Res. 23: 613-621.

[20]. Steward, E. A. (1971). Chemical analysis of ecological materials. Blackwell Scientific Publication, Oxford.

[21]. Usher, M. B. (1975). Some properties of the aggregations of soil arthropods, Cryptostigmata. Pedobiologia. 15: 355-363.

[22]. Wardle, D. A. \& Giller, K. E. (1996). The quest for a contemporary ecological dimension to soil biology. Discussion. Soil Biology and Biochemistry. 28:1549-1554.

[23]. Wilde, S. A., Corey, R. B., Iyer, J. G. and Viogt, G. K. (1985). Soil and plant analysis for tree culture. Oxford and IBH Pub. Co.

[24]. Yang X and Chen J (2009). Plant litter quality influences the contribution of soil fauna to litter decomposition in humid tropical forests, southwestern China.Soil Biology and Chemistry 41: 910-918. 